HETEROCYCLES, Vol. 97, No. 1, 2018, pp. 383 - 394. @ 2018 The Japan Institute of Heterocyclic Chemistry Received, 29th January, 2018, Accepted, 20th March, 2018, Published online, 29th March, 2018 DOI: $10.3987 / \mathrm{COM}-18-\mathrm{S}(\mathrm{T}) 26$

\title{
CONCISE SYNTHESIS OF AZAFLUORENONE AND ITS APPLICATION TO INDENO[1,2-c]ISOQUINOLONE
}

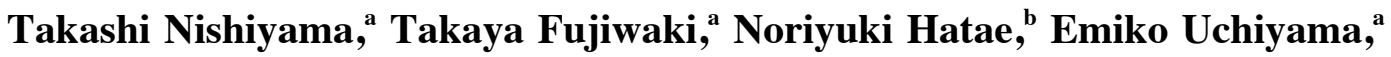 Nao Takeuchi, ${ }^{a}$ Kazuhide Minami, ${ }^{a}$ Chika Yokoyama, ${ }^{a}$ Tomoya Kinoshita, ${ }^{a}$ Minoru Ishikura, ${ }^{\mathrm{b}}$ Satoshi Hibino, ${ }^{\mathrm{a}}$ and Tominari Choshi ${ }^{\mathrm{a} *}$}

${ }^{a}$ Graduate School of Pharmacy \& Pharmaceutical Sciences, Faculty of Pharmacy and Pharmaceutical Sciences, Fukuyama University, Fukuyama, Hiroshima

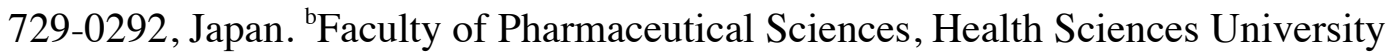
of Hokkaido, Ishikari-Tobetsu, Hokkaido 061-0293, Japan E-mail: choshi@fupharm.fukuyama-u.ac.jp

We dedicate this paper to Professor Dr. Kiyoshi Tomioka on the celebration of his 70th birthday.

\begin{abstract}
The total synthesis of azafluorenone alkaloid, an onychine isolated from Onychopetalum amazonicum, was newly achieved by constructing an azafluorene framework using thermal electrocyclization of the aza $6 \pi$-electron system. This methodology was applied for the synthesis of indeno[1,2-c]isoquinolones as an attractive scaffold for developing anticancer agents.
\end{abstract}

\section{INTRODUCTION}<smiles>CC[C@@]1(O)C(=O)OCc2c1cc1n(c2=O)Cc2cc3ccccc3nc2-1</smiles>

1: camptothecin<smiles>COc1cc2c3c(c(=O)n(C)c2cc1OC)-c1cc2c(cc1C3=O)OCO2</smiles>

2: NSC 314622<smiles>[R]c1cc2c(cc1[R2])-c1nccc(C)c1C2=O</smiles>

3: onychine $\left(\mathrm{R}^{1}=\mathrm{R}^{2}=\mathrm{H}\right)$

4: polyfothine $\left(\mathrm{R}^{1}=\mathrm{R}^{2}=\mathrm{OMe}\right)$

5: isoursuline $\left(\mathrm{R}^{1}=\mathrm{OMe}, \mathrm{R}^{2}=\mathrm{OH}\right)$

Figure 1

Camptothecin (1) is a cytotoxic quinoline alkaloid; its derivatives, irinotecan and topotecan, are used clinically as anticancer drugs. However, the lactone hydrolysis of $\mathbf{1}$ at physiological $\mathrm{pH}$ values results in the loss of its biological activity. ${ }^{1}$ Much research has been performed to evaluate the synthesis and 
activity of its analogs, and the indeno[1,2-c]isoquinolone (tetracyclic azafluorenone) derivative NSC 314622 (2) is considered as a potential anticancer agent with cytotoxic and topoisomerase I (Topo1) inhibitory properties. ${ }^{2}$

Conversely, onychine (3) is an azafluorenone alkaloid that was isolated from Onychopetalum amazonicum in $1976,{ }^{3}$ and has also been reported to exhibit potent antimicrobial activity against multiple bacterial strains. ${ }^{4}$ The first total synthesis of $\mathbf{3}$ was achieved by Prostakov and coworkers. ${ }^{5 a}$ In 2010 , Kraus and coworkers reported the total synthesis of $\mathbf{3}$ using an intramolecular Heck cyclization reaction of 2-bromoaryl 3-pyridyl ketones. ${ }^{51}$ Moreover, the synthesis of $\mathbf{3}$ based on the Pd-catalyzed cross-coupling of arylboronic acid with bromonicotinate has been reported by Snieckus and coworkers. ${ }^{5 \mathrm{~d}}$ Padwa and coworkers achieved its synthesis using the cyclization-deprotonation-cycloaddition cascade of imidosulfoxide. ${ }^{5 i}$ Recently, Marquise and coworkers described the total synthesis of $\mathbf{3}$ using Pd-catalyzed Suzuki coupling-intramolecular arylation auto-tandem reactions. ${ }^{5 \mathrm{q}}$ Till date, the total synthesis of $\mathbf{3}$ (including formal synthesis) has been reported by 17 research groups. ${ }^{5}$ Many synthetic studies are being performed to obtain a new bioactive lead compounds for anticancer agents. Based on the above considerations, azafluorenones and indenoisoquinolones are considered as attractive scaffolds for developing anticancer agents.

We have performed the synthesis of bioactive-fused nitrogen-containing heteroaromatic compounds including natural products and search studies on anticancer agents using them. ${ }^{7,8}$ The total synthesis of bioactive-fused heteroaromatic compounds via the construction of fused pyridine ring systems using a conventional and/or microwave (MW)-assisted thermal electrocyclization of an aza $6 \pi$-electron system has been reported. ${ }^{9}$

In this study, an alternative synthesis of $\mathbf{3}$ by constructing azafluorene based on thermal electrocyclization of a 1 -aza $6 \pi$ electron system is described. Furthermore, this methodology is applied to the synthesis of indeno[1,2-c]isoquinolones.

\section{RESULTS AND DISCUSSION}

Scheme 1 illustrates our retrosynthetic strategy for synthesizing azafluorenone and its derivatives. We envisaged that azafluorenone 6 could be derived from azafluorene 7 via oxidation. The azafluorene 7 might be obtained via thermal electrocyclization of the oxime 8 (as a 1-azahexatriene system), which was derived via cleavage of the 4,4a-bond of the azafluorene framework. The oxime $\mathbf{8}$ can be easily obtained from the known indene 9. 


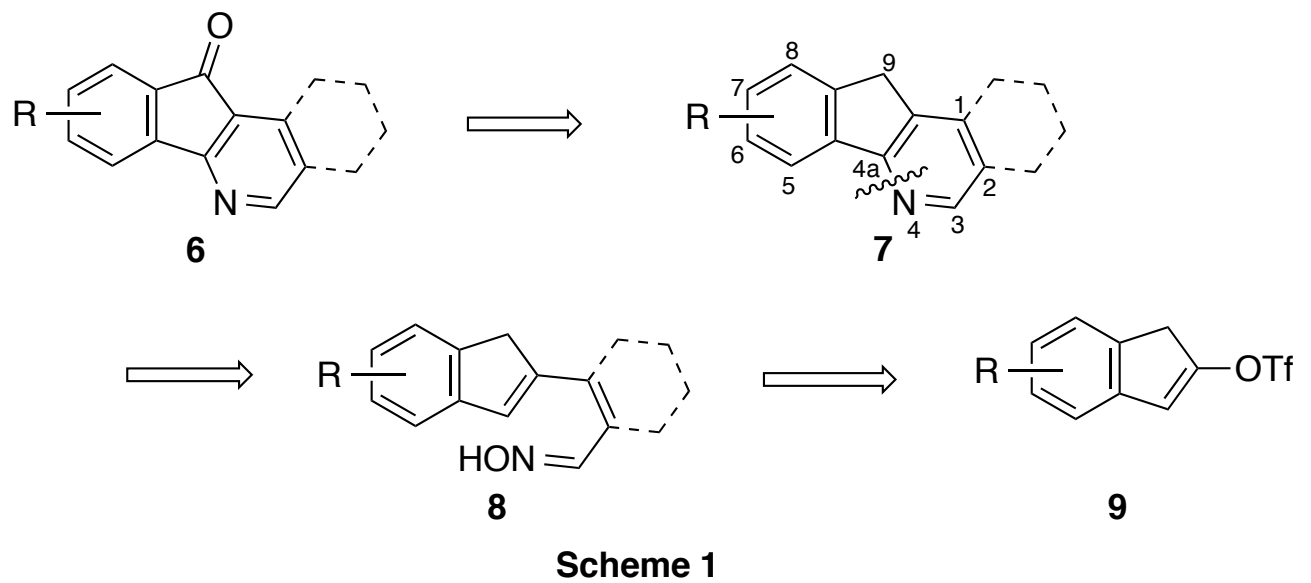

As shown in Scheme 2, 2-(trifluoromethylsulfonyloxy)indene (10) (the starting material) was prepared according to Manabe's procedure. $^{10}$ 2-Alkenylindene $\mathbf{1 1}$ was obtained from triflate $\mathbf{1 0}$ and 3-(tributylstannyl)but-2-en-1-ol ${ }^{11}$ via the Stille reaction ${ }^{12}$ with $85 \%$ yield. Next, conversion from alcohol to oxime was performed using Fukuyama's procedure. $^{13}$ The treatment of $\mathbf{1 1}$ with $O$-TBS- $N$-tosylhydroxylamine via the Mitsunobu reaction, followed by the desilylative elimination of $p$-toluenesulfinate via treatment with $\mathrm{CsF}$, resulted in $76 \%$ yield of oxime 13 (two-step yield).
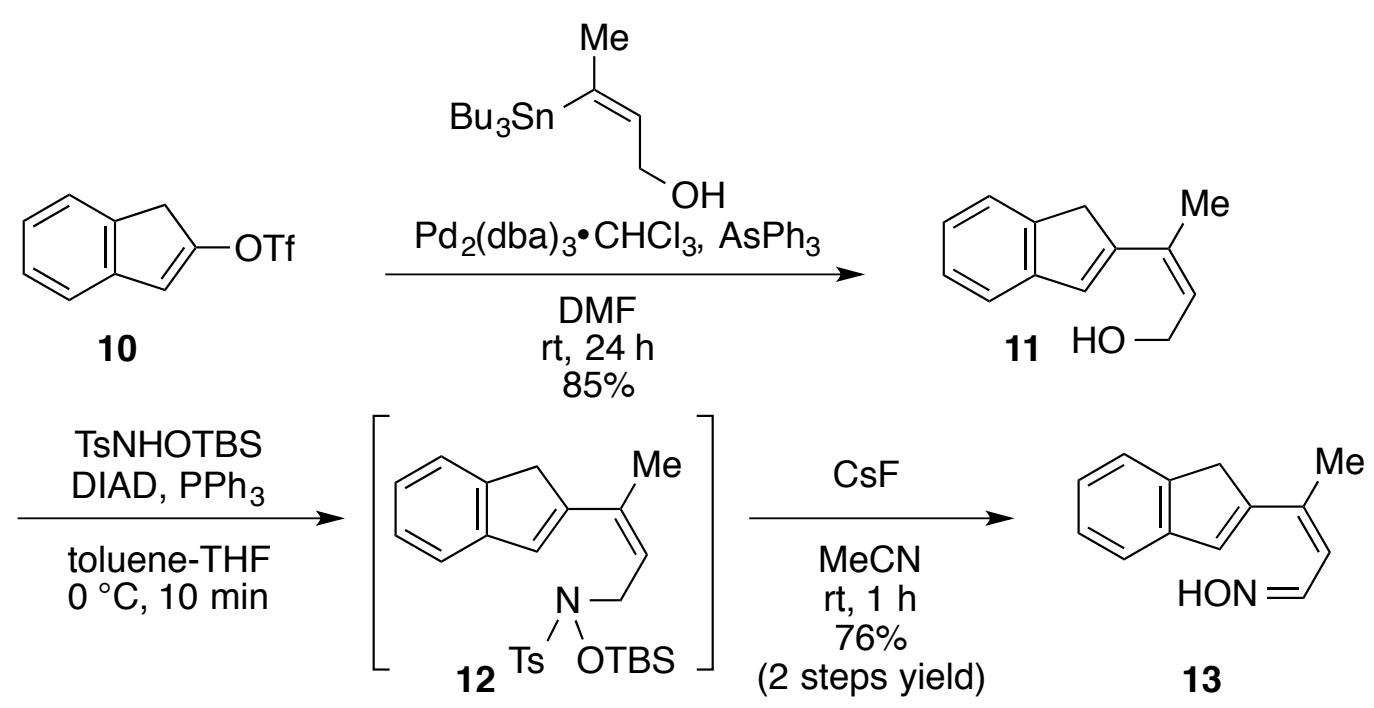

Scheme 2

Subsequently, the synthesis of azafluorene 14 from oxime 13 via electrocyclization was investigated. In addition, the reaction conditions were optimized (solvent type, temperature, and microwave parameters) (Table 1).

First, the heating of $\mathbf{1 3}$ in 1,2-dichlorobenzene at $180{ }^{\circ} \mathrm{C}$ for $10 \mathrm{~min}$ (monitoring the disappearance of oxime 13 via TLC) led to 14 being obtained with $41 \%$ yield (run 1). Subsequently, this reaction was performed in the same solvent at $150{ }^{\circ} \mathrm{C}, 120^{\circ} \mathrm{C}$, and $80{ }^{\circ} \mathrm{C}$ until oxime 13 disappeared, and the heating 
of 13 in the same solvent at $120{ }^{\circ} \mathrm{C}$ resulted in 14 with $60 \%$ yield (runs 2-4). Second, the use of bromobenzene and toluene as solvents (instead of 1,2-dichlorobenzene) was investigated in relation to cyclization conditions (runs 5 and 6). Heating of 13 at $120{ }^{\circ} \mathrm{C}$ in toluene afforded 14 with $64 \%$ yield (run $6)$.

Table 1. Synthesis of $\mathbf{1 4}$ via thermal electrocyclization<smiles>C/C(=C/C=N)C1=Cc2ccccc2C1</smiles>

13

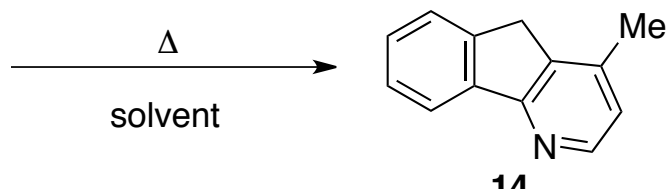

14

\begin{tabular}{clcccc}
\hline Run & \multicolumn{1}{c}{ Solvent } & Temp. $\left({ }^{\circ} \mathrm{C}\right)$ & MW* & Time (h) & Yield (\%) of 14 \\
\hline 1 & 1 1,2-dichlorobenzene & 180 & - & $10 \mathrm{~min}$ & 41 \\
2 & 1 1,2-dichlorobenzene & 150 & - & 1 & 49 \\
3 & 1 1,2-dichlorobenzene & 120 & - & 3 & 60 \\
4 & 1 1,2-dichlorobenzene & 80 & - & 12 & 34 \\
5 & bromobenzene & 120 & - & 1.5 & 43 \\
6 & toluene & 120 & - & 12 & 64 \\
7 & 1,2-dichlorobenzene & 120 & + & 3 & 70 \\
8 & bromobenzene & 120 & + & 1.5 & 36 \\
9 & toluene & 120 & + & 5 & 42 \\
\hline
\end{tabular}

*MW: microwave.

Next, cyclization under MW irradiation was examined and compared with conventional conditions (runs 7-9). When the reaction was performed in 1,2-dichlorobenzene at $120^{\circ} \mathrm{C}$ for $3 \mathrm{~h}$ under MW irradiation, 14 was obtained with $70 \%$ yield (run 7). From the above results, it can be seen that heating at $120{ }^{\circ} \mathrm{C}$ in 1,2-dichlorobenzene under MW irradiation was the best condition for the completion of reaction (run 7).<smiles>Cc1ccnc2c1Cc1ccccc1-2</smiles>

14

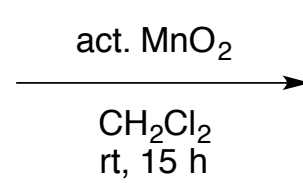

$80 \%$<smiles>Cc1ccnc2c1C(=O)c1ccccc1-2</smiles>

3

Scheme 3

Finally, the oxidation of $\mathbf{1 4}$ with active $\mathrm{MnO}_{2}$ in $\mathrm{CH}_{2} \mathrm{Cl}_{2}$ afforded 3 with $80 \%$ yield (Scheme 3). As described above, we were able to establish the construction methodology of the azafluorenone framework. 


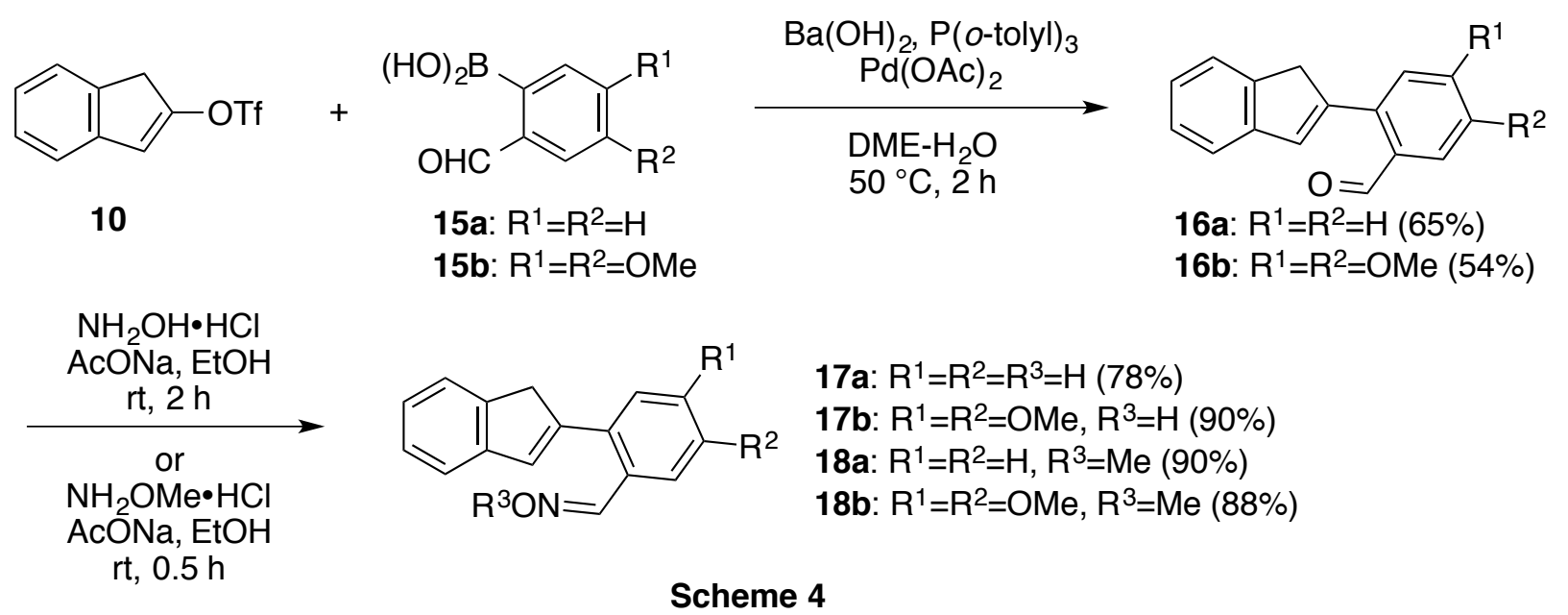

In addition, we applied the above procedure to the synthesis of indeno[1,2-c]isoquinolines (tetracyclic azafluorenone). As shown in Scheme 4, the Suzuki-Miyaura reaction of indene 10 with phenylboronic acids 15a and 15b afforded 2-arylindenes 16a and $16 \mathbf{b}$ with $65 \%$ and $54 \%$ yields, respectively. Subsequently, the treatment of $\mathbf{1 6 a}$ and $\mathbf{1 6 b}$ with hydroxylamine afforded oximes $17 \mathbf{a}$ and $\mathbf{1 7 b}$ with $78 \%$ and $90 \%$ yields, respectively.

Table 2. Synthesis of indeno[1,2-c]isoquinoline via thermal electrocyclization<smiles>[R]c1cc(C=N)c(C2=Cc3ccccc3C2)cc1[R]</smiles>

17a: $R^{1}=R^{2}=R^{3}=H$

17b: $R^{1}=R^{2}=O M e, R^{3}=H$

18a: $R^{1}=R^{2}=H, R^{3}=M e$

18b: $R^{1}=R^{2}=\mathrm{OMe}, \mathrm{R}^{3}=\mathrm{Me}$

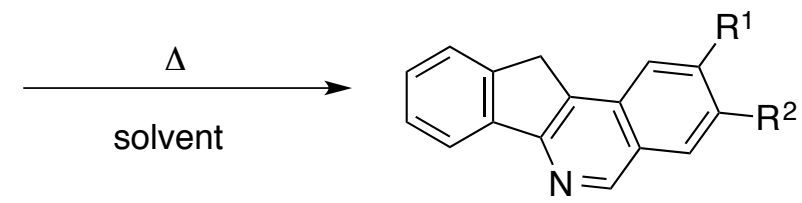

19a: $R^{1}=R^{2}=H$

19b: $R^{1}=R^{2}=\mathrm{OMe}$

\begin{tabular}{cccccccc}
\hline Run & Comd. No. & Solvent & Temp. $\left({ }^{\circ} \mathrm{C}\right)$ & MW & Time $(\mathrm{h})$ & \multicolumn{2}{c}{ Yield $(\%)$} \\
\hline 1 & $\mathbf{1 7 a}$ & 1,2-dichlorobenzene & 180 & - & 15 & 19a & trace \\
2 & $\mathbf{1 7 a}$ & 1,2-dichlorobenzene & 180 & + & 5 & $\mathbf{1 9 a}$ & 32 \\
3 & $\mathbf{1 7 a}$ & diphenyl ether & 260 & - & 1.5 & $\mathbf{1 9 a}$ & 62 \\
4 & $\mathbf{1 7 b}$ & diphenyl ether & 260 & - & 5 & $\mathbf{1 9 b}$ & 50 \\
5 & $\mathbf{1 8 a}$ & diphenyl ether & 260 & - & $45 \mathrm{~min}$ & $\mathbf{1 9 a}$ & 75 \\
6 & $\mathbf{1 8 b}$ & diphenyl ether & 260 & - & 2 & $\mathbf{1 9 b}$ & 77 \\
\hline
\end{tabular}

*MW: microwave. 
Next, to synthesize the indenoisoquinoline, oxime $17 \mathbf{a}$ was heated at $120{ }^{\circ} \mathrm{C}$ in 1,2 -dichlorobenzene under MW irradiation (Table 1, run 7); however, the cyclization reaction did not proceed. Therefore, the optimum conditions for this reaction were further investigated (Table 2). First, 17a was reacted at $180{ }^{\circ} \mathrm{C}$ in 1,2-dichlorobenzene to afford only traces of indenoisoquinoline 19a (run 1). The same reaction was performed under MW irradiation (run 2), giving a slightly improved yield (32\%) compared with run 1. Next, diphenyl ether was used as the solvent. The reaction was carried out without MW irradiation because the MW generator could not be heated to $260{ }^{\circ} \mathrm{C}$. When 17a was heated in diphenyl ether at $260{ }^{\circ} \mathrm{C}$ (run 3), the yield of 19a was improved (62\%) and the reaction time was decreased. Similarly, heating of $\mathbf{1 7 b}$ gave 2,3-dimethoxyindenoisoquinoline $\mathbf{1 9 b}$ in $50 \%$ yield (run 4). Furthermore, to improve the yield, the cyclization reaction using oxime ether instead of oxime was examined with reference to our previous work. ${ }^{14}$ As shown in Scheme $4, \mathbf{1 6 a}$ and $\mathbf{1 6 b}$ were treated with $O$-methylhydroxylamine to give oxime ethers 18a and $\mathbf{1 8 b}$ in $90 \%$ and $88 \%$ yields, respectively.

When oxime ethers 18a and 18b were heated at the same temperature, indenoisoquinolines 19a and 19b were obtained in $75 \%$ and $77 \%$ yields, respectively; moreover, the reaction times were decreased (run 3 vs. run 5 and run 4 vs. run 6). In this case, a high temperature was required for synthesis of the indenoisoquinolines, and oxime ether was a more suitable precursor than oxime. Finally, the oxidation of indenoisoquinolines 19a and 19b with active $\mathrm{MnO}_{2}$ in $\mathrm{CH}_{2} \mathrm{Cl}_{2}$ afforded indenoisoquinolones $20 \mathrm{a}$ and $20 \mathbf{b}$ with $94 \%$ and $60 \%$ yields, respectively (Scheme 5).

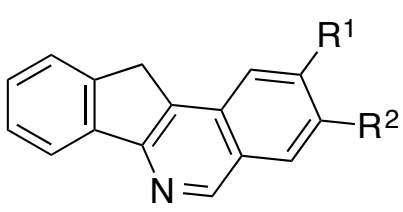

19a: $R^{1}=R^{2}=H$

19b: $R^{1}=R^{2}=\mathrm{OMe}$

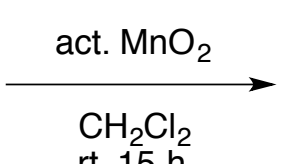

rt, $15 \mathrm{~h}$

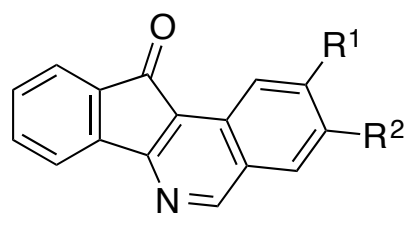

20a: $R^{1}=R^{2}=H(94 \%)$

20b: $R^{1}=R^{2}=\mathrm{OMe}(60 \%)$

Scheme 5

Again, we applied the process to the synthesis of the indenoisoquinolone (tetracyclic azafluorenone) framework. The structures of the azafluorenones and indenoisoquinolones were supported by ${ }^{1} \mathrm{H}-\mathrm{NMR}$, ${ }^{13} \mathrm{C}-\mathrm{NMR}$, and mass spectra.

\section{CONCLUSIONS}

In conclusion, the total synthesis of the azafluorenone alkaloid, onychine (3), was newly achieved by constructing an azafluorene framework using electrocyclization of the 1-aza $6 \pi$-electron system as the key reaction. The target compound $\mathbf{3}$ was obtained in five steps in $36.2 \%$ overall yield from 2-(trifluoromethylsulfonyloxy)indene (10). In addition, this methodology could be applied to the 
synthesis of indeno[1,2-c]isoquinolones (tetracyclic azafluorenone) as an attractive scaffold for developing anticancer agents. The biologic activity of azafluorenones, indenoisoquinolones, and their derivatives is under investigation.

\section{EXPERIMENTAL}

General Methods: All non-aqueous reactions were carried out under an atmosphere of nitrogen in dried glassware unless otherwise noted. Solvents were dried and distilled according to standard protocols. Analytical thin layer chromatography was performed with Silica gel $60 \mathrm{PF}_{254}($ Merck). Silica gel column chromatography was performed with Silica gel 60 (70-230 mesh, Kanto Chemical Co. Lit.). All melting points were determined on Yanagimoto micro melting point apparatus and are uncorrected. ${ }^{1} \mathrm{H}-\mathrm{NMR}$ and ${ }^{13} \mathrm{C}-\mathrm{NMR}$ spectra were recorded on a JEOL AL-300. Infrared spectra were recorded with ATR method using a Shimadzu FTIR-8000 spectrophotometer and Technologies DuraScop. Low and high-resolution mass spectra were recorded on JEOL JMS-700 spectrometers by direct inlet system. The reaction of microwave (MW) irradiation was carried out by Discover of CEM Co. Ltd. with $2450 \mathrm{MHz}$.

3-(Inden-2-yl)but-2-en-1-ol (11): A solution of 3-(tributylstannyl)but-2-en-1-ol (273 mg, $0.76 \mathrm{mmol})$ in $\operatorname{DMF}(5 \mathrm{~mL})$ was added to the mixture of triflate $10(100 \mathrm{mg}, 0.38 \mathrm{mmol}), \mathrm{Pd}_{2}(\mathrm{dba})_{3} \cdot \mathrm{CHCl}_{3}(39 \mathrm{mg}$, $0.038 \mathrm{mmol})$, and $\mathrm{AsPh}_{3}(23 \mathrm{mg}, 0.076 \mathrm{mmol})$ in $\mathrm{DMF}(5 \mathrm{~mL})$. After being stirred at $\mathrm{rt}$ for $24 \mathrm{~h}$, the mixture was quenched with an aqueous KF solution (30\%), and then the mixture was stirred at rt for 30 min. The mixture was filtered through a Celite pad, and extracted with EtOAc. The organic layer was washed with brine, dried over $\mathrm{Na}_{2} \mathrm{SO}_{4}$, and evaporated in vacuo. The residue was purified by column chromatography using EtOAc-hexane (3:7, v/v) as an eluent to give 2-alkenylindene 11 (60 mg, 85\%) as yellow solid. mp $85-86{ }^{\circ} \mathrm{C}\left(\right.$ EtOAc). ${ }^{1} \mathrm{H}-\mathrm{NMR}\left(\mathrm{CDCl}_{3}\right)$ $\delta: 7.44(1 \mathrm{H}, \mathrm{d}, J=7.6 \mathrm{~Hz}), 7.38(1 \mathrm{H}, \mathrm{d}, J=7.6$ $\mathrm{Hz}), 7.27(1 \mathrm{H}, \mathrm{t}, J=7.6 \mathrm{~Hz}), 7.17(1 \mathrm{H}, \mathrm{t}, J=7.6 \mathrm{~Hz}), 6.75(1 \mathrm{H}, \mathrm{s}), 5.68(1 \mathrm{H}, \mathrm{t}, J=6.6 \mathrm{~Hz}), 4.41(2 \mathrm{H}, \mathrm{d}, J$ $=6.6 \mathrm{~Hz}), 3.56(2 \mathrm{H}, \mathrm{s}), 2.06(3 \mathrm{H}, \mathrm{s}), 1.43(1 \mathrm{H}, \mathrm{br} \mathrm{s}) .{ }^{13} \mathrm{C}-\mathrm{NMR}\left(\mathrm{CDCl}_{3}\right)$ $\delta: 145.8,144.5,143.2,134.0$, $130.5,128.1,126.6,124.8,123.5,121.1,60.4,40.8,24.0 . \mathrm{MS} m / z: 186\left(\mathrm{M}^{+}\right)$. HRMS (EI) calcd for $\mathrm{C}_{13} \mathrm{H}_{14} \mathrm{O}$ 186.1045; found 186.1036.

3-(Inden-2-yl)but-2-enal oxime (13): DEAD (40\% in toluene, $0.15 \mathrm{~mL}, 0.32 \mathrm{mmol}$ ) was added slowly to a mixture of 2-alkenylindole $11(150 \mathrm{mg}, 0.81 \mathrm{mmol}), O$-TBS- $N$-tosylhydroxylamine $(218 \mathrm{mg}, 0.72$ $\mathrm{mmol})$, and $\mathrm{PPh}_{3}(424 \mathrm{mg}, 1.62 \mathrm{mmol})$ in toluene $(6 \mathrm{~mL})$ and $\mathrm{THF}(2 \mathrm{~mL})$ at $0{ }^{\circ} \mathrm{C}$. After stirring at the temperature for $10 \mathrm{~min}$, the solvent was evaporated to half an amount. The mixture was dissolved in MeCN (10 mL), and CsF (245 mg, $1.62 \mathrm{mmol}$ ) was added. After stirring at $\mathrm{rt}$ for $1 \mathrm{~h}$, saturated $\mathrm{NH}_{4} \mathrm{Cl}$ aq. was added and extracted with EtOAc. The organic layer was washed with brine, dried over $\mathrm{Na}_{2} \mathrm{SO}_{4}$, and evaporated in vacuo. The residue was purified by column chromatography using EtOAc-hexane (3:7, v/v) as an eluent to give the oxime $13(123 \mathrm{mg}, 76 \%)$ as yellow solid. ${ }^{1} \mathrm{H}-\mathrm{NMR}\left(\mathrm{CDCl}_{3}\right)$ 8: $8.23(2 / 3 \mathrm{H}, \mathrm{d}, J=$ 
$10.4 \mathrm{~Hz}), 7.61(1 / 3 \mathrm{H}, \mathrm{d}, J=10.4 \mathrm{~Hz}), 7.46(1 / 3 \mathrm{H}, \mathrm{d}, J=7.2 \mathrm{~Hz}), 7.42(2 / 3 \mathrm{H}, \mathrm{d}, J=7.2 \mathrm{~Hz}), 7.41(1 \mathrm{H} / 3, \mathrm{~d}$, $J=7.2 \mathrm{~Hz}), 7.36(2 / 3 \mathrm{H}, \mathrm{d}, J=7.2 \mathrm{~Hz}), 7.30(1 / 3 \mathrm{H}, \mathrm{t}, J=7.2 \mathrm{~Hz}), 7.27(1 / 3 \mathrm{H}, \mathrm{t}, J=7.2 \mathrm{~Hz}), 7.23(2 / 3 \mathrm{H}, \mathrm{d}$, $J=7.2 \mathrm{~Hz}), 7.19(2 / 3 \mathrm{H}, \mathrm{d}, J=7.2 \mathrm{~Hz}), 7.00(2 / 3 \mathrm{H}, \mathrm{s}), 6.98(1 / 3 \mathrm{H}, \mathrm{s}), 6.72(1 / 3 \mathrm{H}, \mathrm{d}, J=10.4 \mathrm{~Hz}), 6.43$ $(2 / 3 \mathrm{H}, \mathrm{d}, J=10.4 \mathrm{~Hz}), 3.64(4 / 3 \mathrm{H}, \mathrm{s}), 3.63(2 / 3 \mathrm{H}, \mathrm{s}), 2.20(3 / 3 \mathrm{H}, \mathrm{s}), 2.18(6 / 3 \mathrm{H}, \mathrm{s})$, one proton $(\mathrm{OH})$ was not observed. MS m/z: $199\left(\mathrm{M}^{+}\right)$. HRMS (EI) calcd for $\mathrm{C}_{13} \mathrm{H}_{13} \mathrm{NO}$ 199.0997; found 199.0988.

1-Methyl-4-azafluorene (14): The solution of the oxime 13 (40 mg, $0.21 \mathrm{mmol})$ in 1,2-dichlorobenzene $\left(3 \mathrm{~mL}\right.$ ) was heated under microwave irradiation at $120{ }^{\circ} \mathrm{C}$ for $3 \mathrm{~h}$. After removal of solvent, the residue was purified by column chromatography using EtOAc/hexane $(2: 8, \mathrm{v} / \mathrm{v})$ as an eluent to give the azafluorene $14(27 \mathrm{mg}, 70 \%)$ as orange solid. mp 82-83 ${ }^{\circ} \mathrm{C}(\mathrm{EtOAc}) .{ }^{1} \mathrm{H}-\mathrm{NMR}\left(\mathrm{CDCl}_{3}\right) \delta: 8.47(1 \mathrm{H}, \mathrm{d}, J$ $=4.8 \mathrm{~Hz}), 8.09(1 \mathrm{H}, \mathrm{d}, J=7.5 \mathrm{~Hz}), 7.58(1 \mathrm{H}, \mathrm{d}, J=7.5 \mathrm{~Hz}), 7.45(1 \mathrm{H}, \mathrm{t}, J=7.5 \mathrm{~Hz}), 7.40(1 \mathrm{H}, \mathrm{t}, J=7.5$ $\mathrm{Hz}), 7.01(1 \mathrm{H}, \mathrm{d}, J=4.8 \mathrm{~Hz}), 3.77(2 \mathrm{H}, \mathrm{s}), 2.42(3 \mathrm{H}, \mathrm{s}) .{ }^{13} \mathrm{C}-\mathrm{NMR}\left(\mathrm{CDCl}_{3}\right)$ 8: 159.8, 148.3, 143.3, 143.1, $141.1,136.0,128.4,127.2,125.1,122.4,120.9,33.2,18.5$. MS $m / z: 181\left(M^{+}\right)$. HRMS (EI) calcd for $\mathrm{C}_{13} \mathrm{H}_{11} \mathrm{~N} 181.0891$; found 181.0902 .

Onychine (3): A suspension of the azafluorene 14 (45 mg, $0.25 \mathrm{mmol})$ and active $\mathrm{MnO}_{2}(392 \mathrm{mg}, 2.5$ $\mathrm{mmol})$ in $\mathrm{CH}_{2} \mathrm{Cl}_{2}(10 \mathrm{~mL})$ was stirred at $\mathrm{rt}$ for $15 \mathrm{~h}$. The reaction mixture was filtrated through a Celite pad. The filtrate was evaporated in vacuo. The residue was purified by column chromatography using EtOAc-hexane (3:7, v/v) as an eluent to give onychine (3) $(39 \mathrm{mg}, 80 \%)$ as yellow solid.mp $124-125{ }^{\circ} \mathrm{C}$ (EtOAc) (Lit. $\left.{ }^{6 \mathrm{~g}} \mathrm{mp} 125-127{ }^{\circ} \mathrm{C}\right)$. IR (ATR) v: 1701, $1566 \mathrm{~cm}^{-1} .{ }^{1} \mathrm{H}-\mathrm{NMR}\left(\mathrm{CDCl}_{3}\right) \delta: 8.43(1 \mathrm{H}, \mathrm{d}, J=5.3$ $\mathrm{Hz}), 7.84(1 \mathrm{H}, \mathrm{d}, J=7.5 \mathrm{~Hz}), 7.70(1 \mathrm{H}, \mathrm{d}, J=7.5 \mathrm{~Hz}), 7.59(1 \mathrm{H}, \mathrm{t}, J=7.5 \mathrm{~Hz}), 7.43(1 \mathrm{H}, \mathrm{t}, J=7.5 \mathrm{~Hz})$, $6.97(1 \mathrm{H}, \mathrm{d}, J=5.3 \mathrm{~Hz}), 2.64(3 \mathrm{H}, \mathrm{s}) .{ }^{13} \mathrm{C}-\mathrm{NMR}\left(\mathrm{CDCl}_{3}\right) \delta: 193.2,165.2,152.8,147.5,143.0,135.0$, 134.9, 130.8, 125.9, 125.8, 123.7, 120.7, 17.3. MS m/z: $195\left(\mathrm{M}^{+}\right)$. HRMS (EI) calcd for $\mathrm{C}_{13} \mathrm{H}_{9} \mathrm{NO}$ 195.0684; found 195.0699.

2-(Inden-2-yl)benzaldehyde (16a): A mixture of triflate 10 (140 mg, $0.52 \mathrm{mmol})$, phenylboronic acid 15a (117 mg, $0.78 \mathrm{mmol}), \mathrm{Ba}(\mathrm{OH})_{2}(265 \mathrm{mg}, 0.78 \mathrm{mmol}), \mathrm{P}(o \text {-tolyl })_{3}(30 \mathrm{mg}, 0.1 \mathrm{mmol})$, and $\mathrm{Pd}(\mathrm{OAc})_{2}$ (12 mg, $0.052 \mathrm{mmol})$ in $\mathrm{DME} / \mathrm{H}_{2} \mathrm{O}(4.3 / 0.7 \mathrm{~mL})$ was stirred at $50{ }^{\circ} \mathrm{C}$ for $2 \mathrm{~h}$. The reaction mixture was quenched with water, and then the mixture was extracted with EtOAc. The EtOAc layer was washed with water and brine, dried over $\mathrm{Na}_{2} \mathrm{SO}_{4}$, and evaporated in vacuo. The residue was purified by column chromatography using EtOAc-hexane (1:9, v/v) as an eluent to give the arylindene 16a (74 mg, 65\%) as orange oil. IR (ATR) v: $1682 \mathrm{~cm}^{-1} .{ }^{1} \mathrm{H}-\mathrm{NMR}\left(\mathrm{CDCl}_{3}\right) \delta: 10.26(1 \mathrm{H}, \mathrm{s}), 7.98(1 \mathrm{H}, \mathrm{d}, J=8.0 \mathrm{~Hz}), 7.63(1 \mathrm{H}$, $\mathrm{t}, J=8.0 \mathrm{~Hz}), 7.50-7.54(2 \mathrm{H}, \mathrm{m}), 7.42-7.47(2 \mathrm{H}, \mathrm{m}), 7.34(1 \mathrm{H}, \mathrm{t}, J=7.8 \mathrm{~Hz}), 7.24-7.29(1 \mathrm{H}, \mathrm{m}), 6.85$

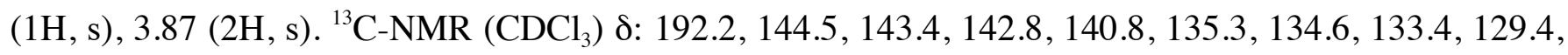
$128.3,127.5,126.9,125.6,123.8,121.5,41.9$. MS $m / z: 220\left(\mathrm{M}^{+}\right)$. HRMS (EI) calcd for $\mathrm{C}_{16} \mathrm{H}_{12} \mathrm{O}$ 220.0888 ; found 220.0856 . 
2-(Inden-2-yl)-4,5-dimethoxybenzaldehyde (16b): The same procedure as above was carried out using phenylboronic acid $\mathbf{1 5 b}$ (100 $\mathrm{mg}, 0.76 \mathrm{mmol})$ to give arylindene $\mathbf{1 6 b}(114 \mathrm{mg}, 54 \%)$ as white solid. $\mathrm{mp}$ 187-188 ${ }^{\circ} \mathrm{C}$ (EtOAc). IR (ATR) v: $1658 \mathrm{~cm}^{-1} .{ }^{1} \mathrm{H}-\mathrm{NMR}\left(\mathrm{CDCl}_{3}\right)$ $\delta: 10.13(1 \mathrm{H}, \mathrm{s}), 7.53(1 \mathrm{H}, \mathrm{d}, J=7.2 \mathrm{~Hz})$, $7.52(1 \mathrm{H}, \mathrm{s}), 7.46(1 \mathrm{H}, \mathrm{d}, J=7.2 \mathrm{~Hz}), 7.34(1 \mathrm{H}, \mathrm{t}, J=7.2 \mathrm{~Hz}), 7.26(1 \mathrm{H}, \mathrm{t}, J=7.2 \mathrm{~Hz}), 6.90(1 \mathrm{H}, \mathrm{s}), 6.85$

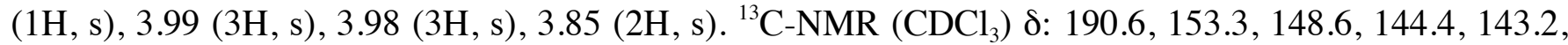
142.2, 136.4, 134.7, 127.9, 126.8, 125.4, 123.7, 121.3, 110.9, 109.1, 56.1, 56.0, 42.3. MS m/z: $280\left(\mathrm{M}^{+}\right)$. HRMS (EI) calcd for $\mathrm{C}_{18} \mathrm{H}_{16} \mathrm{O}_{3} 280.1099$; found 280.1078 .

2-(Inden-2-yl)benzaldehyde oxime (17a): A mixture of arylindene 16a (100 mg, $0.43 \mathrm{mmol}), \mathrm{NH}_{2} \mathrm{OH}$ • $\mathrm{HCl}(59 \mathrm{mg}, 0.86 \mathrm{mmol})$, and AcONa (71 mg, $0.86 \mathrm{mmol})$ in EtOH (5 mL) was stirred at rt for $2 \mathrm{~h}$. After removal of solvent, the mixture was extracted with EtOAc. The EtOAc layer was washed with water and brine, dried over $\mathrm{Na}_{2} \mathrm{SO}_{4}$, and evaporated in vacuo. The residue was purified by column chromatography using EtOAc/hexane $(3: 7, \mathrm{v} / \mathrm{v})$ as an eluent to give the oxime 17a (79 $\mathrm{mg}, 78 \%)$ as white solid. $\mathrm{mp} 187-$

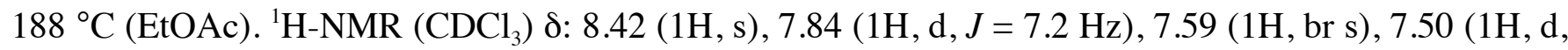
$J=7.2 \mathrm{~Hz}), 7.42-7.46(3 \mathrm{H}, \mathrm{m}), 7.29-7.36(2 \mathrm{H}, \mathrm{m}), 7.24(1 \mathrm{H}, \mathrm{t}, J=7.2 \mathrm{~Hz}), 6.84(1 \mathrm{H}, \mathrm{s}), 3.79(2 \mathrm{H}, \mathrm{s})$.

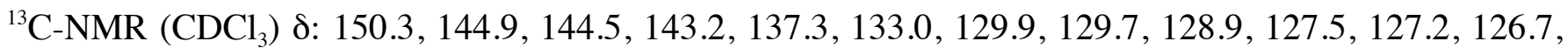
125.2, 123.7, 121.4, 42.1. MS m/z: $235\left(\mathrm{M}^{+}\right)$. HRMS (EI) calcd for $\mathrm{C}_{16} \mathrm{H}_{13} \mathrm{NO}$ 235.0997; found 235.0976.

2-(Inden-2-yl)-4,5-dimethoxybenzaldehyde oxime (17b): The same procedure as above was carried out using arylindene $\mathbf{1 6 b}$ (40 $\mathrm{mg}, 0.14 \mathrm{mmol})$ to give the oxime $\mathbf{1 7 b}(37 \mathrm{mg}, 90 \%)$ as white solid. $\mathrm{mp} 165-$ $167{ }^{\circ} \mathrm{C}\left(\right.$ EtOAc). ${ }^{1} \mathrm{H}-\mathrm{NMR}\left(\mathrm{CDCl}_{3}\right)$ $\delta: 8.39(1 \mathrm{H}, \mathrm{s}), 8.10(1 \mathrm{H}, \mathrm{br} \mathrm{s}), 7.48(1 \mathrm{H}, \mathrm{d}, J=7.4 \mathrm{~Hz}), 7.43(1 \mathrm{H}, \mathrm{d}$, $J=7.4 \mathrm{~Hz}), 7.37(1 \mathrm{H}, \mathrm{s}), 7.31(1 \mathrm{H}, \mathrm{t}, J=7.4 \mathrm{~Hz}), 7.22(1 \mathrm{H}, \mathrm{t}, J=7.4 \mathrm{~Hz}), 6.87(1 \mathrm{H}, \mathrm{s}), 6.78(1 \mathrm{H}, \mathrm{s}), 3.94$

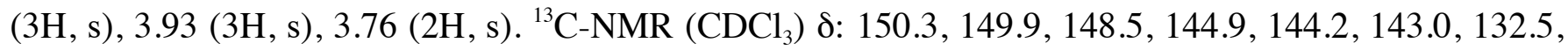
$131.1,126.8,125.0,123.6,122.5,121.3,111.2,108.7,56.0,56.0,42.4$. MS $m / z: 295\left(M^{+}\right)$. HRMS (EI) calcd for $\mathrm{C}_{18} \mathrm{H}_{17} \mathrm{NO}_{3} 295.1208$; found 295.1222.

2-(Inden-2-yl)benzaldehyde $\boldsymbol{O}$-methyloxime (18a): A mixture of arylindene 16a (146 $\mathrm{mg}, 0.43 \mathrm{mmol})$, $\mathrm{NH}_{2} \mathrm{OMe} \cdot \mathrm{HCl}(60 \mathrm{mg}, 0.86 \mathrm{mmol})$, and $\mathrm{AcONa}(71 \mathrm{mg}, 0.86 \mathrm{mmol})$ in $\mathrm{EtOH}(5 \mathrm{~mL})$ was stirred at $\mathrm{rt}$ for $2 \mathrm{~h}$. After removal of solvent, the mixture was extracted with EtOAc. The EtOAc layer was washed with water and brine, dried over $\mathrm{Na}_{2} \mathrm{SO}_{4}$, and evaporated in vacuo. The residue was purified by column chromatography using EtOAc/hexane (3:7, v/v) as an eluent to give the oxime ether 18a (96 $\mathrm{mg}, 90 \%)$ as white solid. mp 68-69 ${ }^{\circ} \mathrm{C}\left(\right.$ EtOAc). ${ }^{1} \mathrm{H}-\mathrm{NMR}\left(\mathrm{CDCl}_{3}\right)$ 8: $8.35(1 \mathrm{H}, \mathrm{s}), 7.89(1 \mathrm{H}, \mathrm{d}, J=7.7 \mathrm{~Hz}), 7.49(1 \mathrm{H}$, $\mathrm{d}, J=7.7 \mathrm{~Hz}), 7.40-7.45(3 \mathrm{H}, \mathrm{m}), 7.28-7.35(2 \mathrm{H}, \mathrm{m}), 7.20-7.25(1 \mathrm{H}, \mathrm{m}), 6.82(1 \mathrm{H}, \mathrm{s}), 3.99(3 \mathrm{H}, \mathrm{s}), 3.77$ $(2 \mathrm{H}, \mathrm{s}) .{ }^{13} \mathrm{C}-\mathrm{NMR}\left(\mathrm{CDCl}_{3}\right) \delta: 148.4,144.9,144.5,143.2,137.1,132.9,129.9,129.5,128.8,127.4,127.1$, 126.7, 125.1, 123.6, 121.3, 61.9, 42.3. MS m/z: $249\left(\mathrm{M}^{+}\right)$. HRMS (EI) calcd for $\mathrm{C}_{17} \mathrm{H}_{15} \mathrm{NO} 249.1154$; found 249.1143 . 
2-(Inden-2-yl)-4,5-dimethoxybenzaldehyde $\boldsymbol{O}$-methyloxime (18b): The same procedure as above was carried out using arylindene $\mathbf{1 6 b}(180 \mathrm{mg}, 0.58 \mathrm{mmol})$ to give the oxime ether $\mathbf{1 8 b}(158 \mathrm{mg}, 88 \%)$ as yellow solid. mp 138-140 ${ }^{\circ} \mathrm{C}\left(\right.$ EtOAc). ${ }^{1} \mathrm{H}-\mathrm{NMR}\left(\mathrm{CDCl}_{3}\right)$ 8: $8.31(1 \mathrm{H}, \mathrm{s}), 7.48(1 \mathrm{H}, \mathrm{d}, J=7.6 \mathrm{~Hz}), 7.43$ $(1 \mathrm{H}, \mathrm{d}, J=7.6 \mathrm{~Hz}), 7.41(1 \mathrm{H}, \mathrm{s}), 7.30(1 \mathrm{H}, \mathrm{t}, J=7.6 \mathrm{~Hz}), 7.21(1 \mathrm{H}, \mathrm{t}, J=7.6 \mathrm{~Hz}), 6.85(1 \mathrm{H}, \mathrm{s}), 6.76(1 \mathrm{H}$, s), $3.98(3 \mathrm{H} \times 2, \mathrm{~s}), 3.93(3 \mathrm{H}, \mathrm{s}), 3.75(2 \mathrm{H}, \mathrm{s}) .{ }^{13} \mathrm{C}-\mathrm{NMR}\left(\mathrm{CDCl}_{3}\right)$ 8: 150.1, 148.4, 148.0, 144.8, 144.2, 143.0, 132.3, 130.9, 126.6, 124.9, 123.5, 122.6, 121.1, 111.1, 108.6, 61.8, 55.9, 55.8, 42.3. MS m/z: 309 $\left(\mathrm{M}^{+}\right)$. HRMS (EI) calcd for $\mathrm{C}_{19} \mathrm{H}_{19} \mathrm{NO}_{3}$ 309.1365; found 309.1334.

Indeno[1,2-c]isoquinoline (19a): The solution of the oxime ether 18a (40 $\mathrm{mg}, 0.17 \mathrm{mmol}$ ) in diphenyl ether $(3 \mathrm{~mL})$ was heated at $260{ }^{\circ} \mathrm{C}$ for $45 \mathrm{~min}$. After removal of solvent, the residue was purified by column chromatography using EtOAc/hexane $(2: 8, \mathrm{v} / \mathrm{v})$ as an eluent to give the indenoisoquinoline 19a (28 mg, 75\%) as yellow solid. mp 157-158 ${ }^{\circ} \mathrm{C}\left(\right.$ EtOAc). ${ }^{1} \mathrm{H}-\mathrm{NMR}\left(\mathrm{CDCl}_{3}\right)$ $\delta: 9.23(1 \mathrm{H}, \mathrm{s}), 8.12(1 \mathrm{H}, \mathrm{d}, J$ $=7.4 \mathrm{~Hz}), 8.01(1 \mathrm{H}, \mathrm{d}, J=8.3 \mathrm{~Hz}), 7.91(1 \mathrm{H}, \mathrm{d}, J=8.3 \mathrm{~Hz}), 7.70(1 \mathrm{H}, \mathrm{t}, J=7.4 \mathrm{~Hz}), 7.60(1 \mathrm{H}, \mathrm{d}, J=7.4$ $\mathrm{Hz}), 7.53(1 \mathrm{H}, \mathrm{t}, J=7.4 \mathrm{~Hz}), 7.47(1 \mathrm{H}, \mathrm{t}, J=7.4 \mathrm{~Hz}), 7.37(1 \mathrm{H}, \mathrm{t}, J=7.4 \mathrm{~Hz}), 4.06(2 \mathrm{H}, \mathrm{s}) .{ }^{13} \mathrm{C}-\mathrm{NMR}$

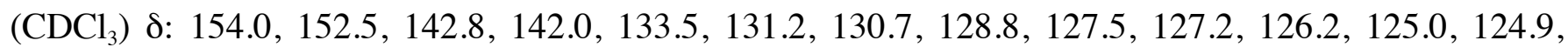
123.1, 120.2, 33.1. MS m/z: $217\left(\mathrm{M}^{+}\right)$. HRMS (EI) calcd for $\mathrm{C}_{16} \mathrm{H}_{11} \mathrm{~N} 217.0891$; found 217.0883.

2,3-Dimethoxyindeno[1,2-c] isoquinoline (19b): The same procedure as above was carried out using the oxime ether $18 \mathbf{b}(55 \mathrm{mg}, 0.18 \mathrm{mmol})$ to give the indenoisoquinoline 19b (38 $\mathrm{mg}, 77 \%)$ as yellow solid. mp 218-220 ${ }^{\circ} \mathrm{C}\left(\right.$ EtOAc). ${ }^{1} \mathrm{H}-\mathrm{NMR}\left(\mathrm{CDCl}_{3}\right)$ 8: $9.05(1 \mathrm{H}, \mathrm{s}), 8.09(1 \mathrm{H}, \mathrm{d}, J=7.6 \mathrm{~Hz}), 7.61(1 \mathrm{H}, \mathrm{d}, J=7.6$ $\mathrm{Hz}), 7.47(1 \mathrm{H}, \mathrm{t}, J=7.6 \mathrm{~Hz}), 7.37(1 \mathrm{H}, \mathrm{t}, J=7.6 \mathrm{~Hz}), 7.28(1 \mathrm{H}, \mathrm{s}), 7.12(1 \mathrm{H}, \mathrm{s}), 4.09(3 \mathrm{H}, \mathrm{s}), 4.05(3 \mathrm{H}, \mathrm{s})$,

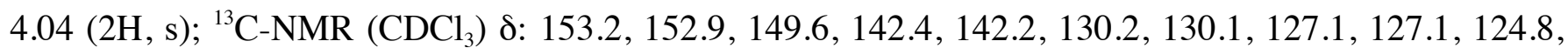
123.5, 123.4, 119.9, 106.3, 101.5, 56.0, 55.9, 33.1. MS m/z: $277\left(\mathrm{M}^{+}\right)$. HRMS (EI) calcd for $\mathrm{C}_{18} \mathrm{H}_{15} \mathrm{NO}_{2}$ 277.1103; found 277.1111.

Indeno[1,2-c]isoquinolin-11-one (20a): A suspension of the indenoisoquinoline 19a (18 $\mathrm{mg}, 0.053$ mmol) and active $\mathrm{MnO}_{2}(22 \mathrm{mg}, 0.25 \mathrm{mmol})$ in $\mathrm{CH}_{2} \mathrm{Cl}_{2}(3 \mathrm{~mL})$ was stirred at $\mathrm{rt}$ for $15 \mathrm{~h}$. The reaction mixture was filtrated through a Celite pad. The filtrate was evaporated in vacuo. The residue was purified by column chromatography using EtOAc/hexane $(1: 1, \mathrm{v} / \mathrm{v})$ as an eluent to give the indenoisoquinolone 20a (12 mg, 94\%) as white solid. mp 242-243 ${ }^{\circ} \mathrm{C}(\mathrm{EtOAc}) .{ }^{1} \mathrm{H}-\mathrm{NMR}\left(\mathrm{CDCl}_{3}\right)$ 8: $9.27(1 \mathrm{H}, \mathrm{s}), 8.78(1 \mathrm{H}, \mathrm{d}$, $J=8.3 \mathrm{~Hz}), 7.95(1 \mathrm{H}, \mathrm{d}, J=8.3 \mathrm{~Hz}), 7.76-7.82(2 \mathrm{H}, \mathrm{m}), 7.67(1 \mathrm{H}, \mathrm{d}, J=7.0 \mathrm{~Hz}), 7.51-7.58(2 \mathrm{H}, \mathrm{m})$, $7.36(1 \mathrm{H}, \mathrm{t}, J=7.0 \mathrm{~Hz}) .{ }^{13} \mathrm{C}-\mathrm{NMR}\left(\mathrm{CDCl}_{3}\right) \delta: 194.1,162.3,158.2,143.7,134.8,134.5,133.5,132.4$, 130.3, 129.1 , 128.6, 127.5, 123.7, 123.4, 120.5, 119.6. MS m/z: $231\left(\mathrm{M}^{+}\right)$. HRMS (EI) calcd for $\mathrm{C}_{16} \mathrm{H}_{9} \mathrm{NO}_{2}$ 231.0684 ; found 231.0688 .

2,3-Dimethoxyindeno[1,2-c]isoquinolin-11-one (20b): The same procedure as above was carried out using indenoisoquinoline $\mathbf{1 9 b}$ (30 $\mathrm{mg}, 0.14 \mathrm{mmol}$ ) to give the indenoisoquinolone $20 \mathrm{~b}(24 \mathrm{mg}, 60 \%)$ as 
yellow solid. mp 262-263 ${ }^{\circ} \mathrm{C}\left(\right.$ EtOAc). ${ }^{1} \mathrm{H}-\mathrm{NMR}\left(\mathrm{CDCl}_{3}\right)$ 8: $8.97(1 \mathrm{H}, \mathrm{s}), 8.03(1 \mathrm{H}, \mathrm{s}), 7.74(1 \mathrm{H}, \mathrm{d}, J=$ $7.2 \mathrm{~Hz}), 7.61(1 \mathrm{H}, \mathrm{d}, J=7.2 \mathrm{~Hz}), 7.51(1 \mathrm{H}, \mathrm{t}, J=7.2 \mathrm{~Hz}), 7.32(1 \mathrm{H}, \mathrm{t}, J=7.2 \mathrm{~Hz}), 7.12(1 \mathrm{H}, \mathrm{s}), 4.10(3 \mathrm{H}$, s), $4.02(3 \mathrm{H}, \mathrm{s}) .{ }^{13} \mathrm{C}-\mathrm{NMR}\left(\mathrm{CDCl}_{3}\right) \delta: 194.5,160.9,156.0,154.5,150.6,143.9,134.7,134.6,129.9,129.8$, 125.7, 123.4, 120.1, 118.8, 105.9, 101.3, 56.5, 56.0. MS m/z: $291\left(\mathrm{M}^{+}\right)$. HRMS (EI) calcd for $\mathrm{C}_{18} \mathrm{H}_{13} \mathrm{NO}_{3}$ 291.0895; found 291.0867.

\section{ACKNOWLEDGEMENTS}

This work was supported in part by a Grant-in-Aid for Scientific Research (C) of the Japan Society for the Promotion of Science (grant number 15K07880 for T.C.).

\section{REFERENCES AND NOTES}

1. M. E. Wall, M. C. Wani, C. E. Cook, K. H. Palmer, A. T. McPhail, and G. A. Sim, J. Am. Chem. Soc., 1966, 88, 3888 .

2. (a) A. Morrell, M. Placzek, S. Parmley, B. Grella, S. Antony, Y. Pommier, and M. Cushman, J. Med. Chem., 2007, 50, 4388; (b) M. Cushman and L. Cheng, J. Org. Chem., 1978, 43, 3781; (c) M. Cushman and L. Cheng, J. Org. Chem., 1978, 43, 286.

3. M. E. L. De Almeida, F. R. Braz, V. von Bülow, O. R. Gottlieb, and J. G. S. Maia, Phytochemistry, 1976, 15, 1186.

4. (a) C. D. Hufford, S. Liu, A. M. Clark, and B. O. Oguntimein, J. Nat. Prod., 1987, 50, 961; (b) J. Koyama, I. Morita, N. Kobayashi, T. Osakai, Y. Usuki, and M. Taniguchi, Bioorg. Med. Chem. Lett., 2005, 15, 1079.

5. (a) N. S. Prostakov, V. G. Pleshakov, T. S. Seitembetov, D. A.Fesenko, and O. L. Olubajo, Zh. Org. Khim., 1977, 13, 1484; (b) N. S. Prostakov, A. T. Soldatenkov, P. K. Radzhan, V. O. Fedorov, A. A. Fomichev, and V. A. Rezakov, Khim. Geterotsikl. Soedin., 1982, 513; (c) T. Okatani, J. Koyama, Y. Suzuta, and K. Tagahara, Heterocycles, 1988, 27, 2213; (d) T. Alves, A. B. De Oliveira, and V. Snieckus, Tetrahedron Lett., 1988, 29, 2135; (e) F. Bracher, Arch. Pharm., 1989, 322, 293; (f) T.-H. Tong and H. N. C. Wong, Synth. Commun., 1992, 22, 1773; (g) M. Nitta, M. Ohnuma, and Y. Iino, J. Chem. Soc., Perkin Trans. 1, 1991, 1115; (h) R. Sreekumar, P. Rugmini, and R. Padmakumar, Synth. Commun., 1998, 28, 2071; (i) A. Padwa, T. M. Heidelbaugh, and J. T. Kuethe, J. Org. Chem., 2000, 65, 2368; (j) A.-S. Rebstock, F. Mongin, F. Trecourt, and G. Queguiner, Tetrahedron, 2004, 60, 2181; (k) B.-C. Hong, M. Hallur, and J.-H. Liao, Synth. Commun., 2006, 36, 1521; (1) G. A. Kraus and A. Kempema, J. Nat. Prod., 2010, 73, 1967; (m) K. N. Clary and T. G. Back, Synlett, 2010, 2802; (n) S. Zhang, L.-Y. Liao, F. Zhang, and X.-F. Duan, J. Org. Chem., 2013, 78, 2720; (o) N. Marquise, V. Dorcet, F. Chevallier, and F. Mongin, Org. Biomol. Chem., 2014, 12,8138; (p) S. 
Taghavi-Moghadam, C. D. Kwong, J. A. Secrist, S. I. Khan, and A. M. Clark, Bioorg. Med. Chem., 2016, 24, 6119; (q) N. Marquise, F. Chevallier, E. Nassar, M. Frederich, A. Ledoux, Y. S. Halauko, O. A. Ivashkevich, V. E. Matulis, T. Roisnel, V. Dorcet, and F. Mongin, Tetrahedron, 2016, 72, 825.

6. C. C. Lee, D.-M. Chang, K.-F. Huang, C.-L. Chen, T.-C. Chen, Y. Lo, J.-H. Guh, and H.-S. Huang, Bioorg. Med. Chem., 2013, 21, 7125.

7. (a) S. Hibino and E. Sugino, In Advances in Nitrogen Heterocycles, ed. by C. J. Moody, JAI Press, Greenwich, CT (USA), 1995, 1, 205; (b) T. Choshi, Yakugaku Zasshi, 2001, 121, 487; (c) T. Choshi and S. Hibino, Heterocycles, 2009, 77, 85; (d) T. Choshi and S. Hibino, Heterocycles, 2011, 83, 1205 , and related references cited therein.

8. (a) T. Nishiyama, N. Hatate, M. Mizutani, T. Yoshimura, T. Kitamura, M. Miyano, M. Fujii, N. Satsuki, M. Ishikura, S. Hibino, and T. Choshi, Eur. J. Med. Chem., 2017, 136, 1; (b) T. Nishiyama, N. Hatae, T. Yoshimura, S. Takaki, T. Abe, M. Ishikura, S. Hibino, and T. Choshi, Eur. J. Med. Chem., 2016, 121, 561; (c) Y. Kurata, T. Choshi, Y. Ishihara, N. Hatae, T. Nishiyama, and S. Hibino, Heterocycles, 2014, 88, 297.

9. (a) Y. Ishihara, S. Azuma, T. Choshi, K. Kohno, K. Ono, H. Tsutsumi, T. Ishizu, and S. Hibino, Tetrahedron, 2011, 67, 1320; (b) T. Choshi, T. Kumemura, H. Fujioka, Y. Hieda, and S. Hibino, Heterocycles, 2012, 84, 587; (c) S. Tagawa, T. Choshi, A. Okamoto, T. Nishiyama, S. Watanabe, N. Hatae, M. Ishikura, and S. Hibino, Eur. J. Org. Chem., 2013, 1805, and related references cited therein; (d) T. Nishiyama, N. Hatate, K. Hayashi, M. Obata, K. Taninaka, M. Yamane, S. Oda, T. Abe, M. Ishikura, S. Hibino, and T. Choshi, Heterocycles, 2017, 95, 251, and related references cited therein.

10. T. Ueda, H. Konishi, and K. Manabe, Org. Lett., 2012, 14, 5370.

11. B. H. Lipshutz, G. C. Clososki, W. Chrisman, D. W. Chung, D. B. Ball, and J. Howell, Org. Lett., $2005,7,4561$.

12. A. Wada, Y. Mizuguchi, M. Shinmen, M. Ito, K. Nakagawa, and T. Okano, Lett. Drug Des. Discov., 2006, 3, 2, 118.

13. K. Kitahara, T. Toma, J. Shimokawa, and T. Fukuyama, Org. Lett., 2008, 10, 2259.

14. (a) T. Choshi, T. Kumemura, J. Nobuhiro, and S. Hibino, Tetrahedron Lett., 2008, 49, 3725; (b) Y. Tazaki, Y. Tsuchiya, T. Choshi, T. Nishiyama, N. Hatae, H. Nomoto, and S. Hibino, Heterocycles, 2014, 89, 427. 